Volume 5, Issue 2

\title{
Rental Values and Students' Satisfaction in Private Hostels Proximate to the Federal University of Technology, Akure, Nigeria
}

\author{
Victoria Amietsenwu Bello ${ }^{1}$ and Nnaemeka Bethel Ezeokoli ${ }^{2}$ \\ 1-2 Department of Estate Management, Federal University of Technology, Nigeria.
}

To cite this article: Bello, V.A. \& Ezeokoli, N.B. (2020). Rental Values and Students' Satisfaction in Private Hostels Proximate to the Federal University of Technology, Akure, Nigeria. Journal of African Real Estate Research, 5(2), pp.41-58. DOI: 10.15641/jarer.v5i2.839.

\begin{abstract}
Property rental values are readily influenced by a multitude of interrelated factors such as the state of the economy, neighbourhood amenities and property characteristics. However, there is always an expectation that rental value reflects the occupier's satisfaction from the neighbourhood and property. As such, this study examines the satisfaction of students with private hostel facilities surrounding the Federal University of Technology Akure (FUTA), and the effect these facilities have on the rental values of the off-campus students' hostels. There are 17,307 students who reside in the private hostels off-campus, of which 392 students were randomly selected from the total population of residents living around FUTA South Gate and given questionnaires. Of the 392 questionnaires administered, 390 were retrieved for analysis, thus representing a 99.5\% response rate. The data collected was then analyzed using the Weighted Mean Score (WMS), T-test Statistics, Spearman Rank Correlation and the Multiple Regression Analyses. The findings reveal that there is a significant difference in the rental price paid by satisfied and unsatisfied students. Thus, the satisfied students pay higher rents than the non-satisfied students for a single, self-contained apartment. These occupiers are found to be satisfied with facilities such as the toilet, bathroom, fencing and water supply system in the building. There is a positive relationship between students' rent satisfaction and their satisfaction with hostel facilities provided. The regression analysis further reveals that rental value is a function of neighbourhood amenities and property characteristics. The study recommends that private hostel developers make adequate provision for functional facilities as these can increase students' satisfaction as well as enhance residential property rental values.
\end{abstract}

Keywords: Student Housing Facilities; Private Hostels; Rental Values; Satisfaction, Nigeria 


\section{Introduction}

Access Housing is both a consumable and investment good and so this type of investment is capital intensive (Henderson \& Loannides, 1987; Ezinuo, Onyejiaka \& Emoh, 2014). According to Thorncroft (1978), the aim of real estate investment, especially housing, could be for pecuniary or nonpecuniary benefits. Investment could be in the commercial, residential and industrial sectors among others. However, the residential sector includes investment in dwelling houses of which student housing accommodation is a part. Students are a section of the population that forms a specific key demand group for housing because of the niche market they create and bring about material difference in their demand from other tenants (Rugg, Rhodes \& Jones, 2000). In many developed and developing countries the world over, the provision of accommodation for student populations continues to be a challenge to most governments. This may be because of the annual increase in the enrolment of students in the tertiary institutions worldwide and weak or no policy directed at housing them (Rugg, Rhodes \& Jones, 2000). Sharma (2012) observes that student-enrolment in institutions of higher education has increased to about $160 \%$ globally. Furthermore, Horn, Peter and Rooney (2002) reveal that out of the estimated 16 million students attending colleges and universities in the United Kingdom, approximately $16 \%$ of them live on campus, while the remaining population resides off-campus.

In Nigeria, little or no attention has been given to the provision of adequate accommodations in these universities to take care of the rising student population. Nigeria University Commission's (NUC) statistics show that the government's provision for student housing is less than $30 \%$ of the demand (NUC, 2004). Also, Adebisi et al. (2015) observed that the rate of hostel provision by government is decreasing with increasing population of students. Therefore, the national government has adopted policies that encourage private participation in the provision of student accommodation to solve the under-supply of student housing as well as support the inadequate residential infrastructure provided by the government (Asare-Kyrie et al., 2012). Despite this laudable objective, student housing on campus and off campus remain grossly inadequate in Nigeria.

The Federal University of Technology Akure, which was established in 1982, operates the dual-residential accommodation system where some students (especially the first year and the final year students) are accommodated oncampus, while others are made to seek accommodation outside the institution. The reason for this duality is the inability of the institution to accommodate its growing student numbers coupled with little or no subvention from government. For instance, during the University's inaugural academic year (1982/1983), 147 students were enrolled. This number grew to 19,230 in the 2017/2018 academic session (FUTA Academic Planning unit, 2018). Out of the 19,230 students in the $2017 / 2018$ academic session, only 790 females and 1,133 male students (a total of 1,923 students) were accommodated in the university's student hostels on-campus. Thus, private property investors cater for the large percentage of students who are not in the university's residential facilities (school hostels) as to complement government's efforts. The rent 
charged by private developers is typically exorbitant, with lackluster facilities (Olatubara, 2008). It is frequently observed that these properties are in poor state of repair, overcrowded, having inadequate facilities, dirty and unpleasant conditions (Ubong, 2007; Aluko, 2011; Idakwo, Igbokwo \& Ndom, 2012). The question, therefore, is whether students are satisfied with the facilities provided in their privately rented off-campus hostels as well as the rent they pay for these accommodations. Does any relationship exist between students' satisfaction with the facilities provided and rent satisfaction? And, what effect does the provision of facilities have on rental values of hostel accommodation? These are the questions this paper aims to address.

The paper is organised as follows. The following section (Section 2) takes the form of a literature review. The review is followed by a discussion of the research methodology in Section 3 with the results presented and analyzed in Section 4. The paper concludes with a summary of findings, recommendations and a conclusion in Section 5.

\section{Literature Review}

According Housing is not only a basic human need, but it constitutes a vital component of welfare, life sustenance and survival (Bello \& Bello, 2006). According to MacLaren (1996), one of the characteristics of sustainable development is satisfying basic human needs. These needs may include safety and satisfaction of users or consumers. They are elements that improve the well-being of humans and their surrounding ecosystem (Hodge, 1997). Therefore, understanding the need for sustainable housing development visà-vis its role in ensuring human safety, health and satisfaction will go a long way in shaping the face of housing developments in the society. More especially that of students. Given the foundational role housing plays in human wellbeing, many researchers have studies in the field (Egunjobi, 1999; Ajanlekoko, 2001; Olujimi, 2010). However, tertiary student accommodation has had little interest for Nigerian researchers. Internationally student accommodation has gained academic interest. In developed countries, studies have focused on students' housing satisfaction (Thomsen \& Eikemo, 2010) and the factors predicting student's satisfaction with university hostels (Khozaei, et al., 2010). Contrastingly, the few studies on student housing in developing countries (including Nigeria), have focused on the modes of transportation taken by non-resident university students (Nkegbe, Kuunibe and Abdul - Mumin, 2012); student access to housing and management (Joachim and Olachi, 2010; Yusuff, 2011; Mohammad, Gambo and Omirin 2012); student's accommodation quality and the economics of private hostels (Asare-Kyire, Appienti, Forkwoh and Osei, 2012; Nimako and Bondinuba, 2013) risk in student hostel investment (Attakora-Amaniampong, Salakpi and Quansah, 2014) and student hostel accommodation alongside academic performance (Oyetunji, 2014).

For instance, Yusuf's (2011) study on student access to housing in Lagos State University made use of a Percentage Frequency Table. The study revealed that most students suffer from an incessant increase in housing rent, 
domestic violence and neighbourly disturbances. However, the study did not look at the factors affecting the increase in rental value of the student housing. On the other hand, Aluko (2011) assessed the condition of students' housing at the University of Lagos as well as the level of satisfaction students felt with the state of the facilities. The study, which focused on on-campus housing facilities used a structured questionnaire and interviewed over 400 students. This data was then analyzed using Frequency Distribution Tables and graphs which suggest that the demand places immense pressure on the undersupply housing facilities within the institution. This imbalance, coupled with the deplorable condition and maintenance of these properties, caused greater dissatisfaction among the student-users. Akhihiero (2011) argues that the poor state of student accommodation facilities in tertiary education in Nigeria could result in high levels of stress among students and consequently poor academic performance. Furthermore, the overcrowding of student-on-campus housing facilities erodes the privacy that most students seek (Aluko, 2011). This has forced many students to search for private, safe and convenient accommodation outside the campus despite the higher associated costs (Khozaei, Hassan \& Razak, 2011). Olaniyan, et al. (2018) similarly argues that the supply of electricity, which typically between 4-8 hours per day across the country, has implications on students' social and academic performance as well as overall sustainable development (Akhihiero, 2011). The cost of private accommodation is also unsustainable for students. The rate at which the rent of off-campus student hostels is increasing is exponential. This increase is a cause for concern as it suggests that the factors that should normally be assessed before fixing rents are often neglected (Mudau, 2017). Such factors as good housing conditions, functional facilities, access road and good water supply that are necessary for good living are often not available in some of the students' housing notwithstanding the high rent the housing commands.

Looking more globally, Khozaei, Hassan and Khozaei (2010) assess undergraduate students' satisfaction with hostel and their sense of attachment to place in University Sains, Malaysia. The study uses a dataset of 267 undergraduate student respondents, and correlation analysis was employed to measure the association of students' satisfaction with the attachment to the place. It was found that increased satisfaction level is associated with higher sense of attachment, which was found to be significant. Additionally, a study by Sawyerr and Yusof (2013) examined the levels of student-satisfaction with the facilities provided within their on-campus hostels in Malaysia using a sample of 250 students. Descriptive statistics were analyzed, and the results suggest that the majority of the students are not satisfied with the facilities in their hostels, and not all were equipped with the facilities necessary for convenient or conducive living by the homeowners for. This highlights the deplorable state of the housing provided outside the university campuses as the developers are more profit-driven rather than human-centred as little or no income is plowed back into the building for maintenance (Ogeah \& Ajalaye, 2011; Mudau, 2017). Contrastingly, Danso and Hammond's (2017) study of Ghana, reveals that students were satisfied with the quality of the facilities provided in off-campus hostels. However, the service delivery of the hostel managers was called into question for adequate improvement. 
Attakora-Amaniampong, Ameyaw and Akortsu (2017) also found the hostels and facilities in Wa Town, Ghana, tend to be adequate in meeting the requirements of the students for academic purposes.

Returning to Nigeria, Mbee and Akpoghomeh (2017) examine the trend in off-campus student accommodation rents in federal public universities in Southern Nigeria using both descriptive and inferential statistics. The result shows a significant variation in the rental pattern of student's accommodation across the universities and geographical locations. There is no denying that each student carves out a niche in the housing market, which is different from others (Adebisi et al., 2015), and one which landlords may seize as an opportunity to increase rents arbitrarily without providing the required facilities to command such rents. Furthermore, Azeez, Taiwo, Mogaji-Allison and Bello (2016) comparatively assess students' satisfaction with private hostels in selected private Universities in Ogun State, Nigeria. Their study employs a relative satisfaction index to determine the degree of student's satisfaction with varying housing components. They conclude that student's satisfaction with hostel accommodation can be significantly influenced by the standard of housing components. However, the study was unable to show if there is any relationship between students' satisfaction with hostel accommodation and satisfaction with rent paid for the use of such accommodation. Adebisi et al. (2017) also examine the perspective of students on private hostel facilities in proximity to the Federal University of Technology in Akure using a relative importance index and weighted mean score. The results reveal that students need internet connectivity and electricity facilities, both of which but are largely unavailable for them. Privacy and the length of lease were the major points of attraction for students. Finally, Attakora-Amaniampong et al. (2017) observe the risks associated with private student housing investment, especially when the investment environment is unstable. These risks include management risks, which raked highest, environmental risks, inflation, legislative, liquidity to the lowest ranked financial risk.

Under normal circumstances, and according to the literature, there should be a positive correlation between satisfaction with the facilities in the student housing and rent paid for using such facilities. However, in some cases in Nigeria, these facilities that should enhance student-satisfaction are either inadequately provided, maintained or altogether unavailable (Adebisi, et al., 2017). The literature above highlights this, however it also highlights a gap in the existing research. The authors have not been able to prove whether students' rent satisfaction is a function of student's satisfaction with housing facilities. Thus, the present study deviates from previous studies and investigates the students' satisfaction with rental paid on off-campus housing in relation to on-campus facilities in the study area. The intent of this is to fill the present knowledge gap and to add to available literature.

\section{Research Methodology}

This study focuses on the rental values and satisfaction of students with offcampus hostel facilities around FUTA South Gate. The term 'private hostel', 
as used in this study, refers to any student housing or residential property occupied by the students in the study area that is not provided by the university of by government. The target population for the study comprises the student population living in off-campus hostels around FUTA South Gate. According to the record of FUTA Academic Planning Unit (2018), the population of the students is 19,230 out of which 1,923 live on the campus. Therefore, 17,307 FUTA students live in private hostels located outside the university campus and it is from this group that the target population is drawn. Using Kothari's (2004) formula, 392 students were determined as the sample size for the study. This is the minimum sample size according to Kothari. In order to achieve a good response rate, more than 392 questionnaires were administered, randomly, to students living in private hostels off-campus around FUTA South Gate. A total of 390 of the questionnaires retrieved were found good for analysis giving a response rate of $99.5 \%$ of the sample size. The data gathered was analyzed using the Weighted Mean Score, Spearman's Rank Correlation and Multiple Regression Analysis.

The Weighted Mean Score was used to examine the level of students' satisfaction with the facilities in the off-campus accommodation they occupy. The response was ranked on a 5-point Likert scale ranging from 'highly satisfied' with a weight of 5 points to 'highly dissatisfied' with a weight of 1 . The formula for determining the weighted mean score or average is as shown in equation (1).

$$
\ddot{\mathrm{x}}_{w}=\frac{\sum_{i}^{N} x_{i} w_{i}}{\sum_{i}^{N} w_{i}}
$$

Where: $\ddot{x}_{w}$ is the weighted item; $x_{i}$ is the value of the $\mathrm{i}^{\text {th }}$ item $\mathrm{x} ; w_{i}$ is the weight of the $i^{\text {th }}$ item $x$.

The satisfaction of students with the rent they pay, and facilities provided in their off-campus hostels were ranked on 2-point and 5-point Likert scales respectively. Thereafter, Spearman's Rank Correlation, which measures the strength of association between two variables, was employed in measuring the association between the rent satisfaction of the students and their satisfaction with facilities provided in the off-campus hostels. This statistical method uses ranks and is appropriate for both continuous and discrete ordinal variables. The formula is shown in equation (2).

$$
r_{s}=1-\frac{6 \sum d_{i}^{2}}{n\left(n^{2}-1\right)}
$$

Where: $r_{s}$ is the correlation coefficient; $d_{i}$ is the difference between the two ranks of each observation; ' $n$ ' is the number of observations.

A Multiple Regression Model was used to analyze the effect of facilities on the rental values of the properties occupied by the students. The regression analysis deals with the contribution of the independent variables to changes or variations in the dependent variable. This is represented by equation (3).

$$
\begin{gathered}
R E N T=\alpha+\beta_{1} \text { TOFAC }+\beta_{2} \text { WATSUP }+\beta_{3} B A T H+\beta_{4} E L E C+\beta_{5} F E N C E+ \\
\beta_{6} A C C+\beta_{7} S E C S Y S T+\mu
\end{gathered}
$$


Where: $\alpha$ is the constant; $\beta_{i}$ is beta coefficient of variables, $\mathrm{i}$, which measures the changes in rent that associated with a unit change in the independent variables; $\mu$ is the error term associated with the variables.

Table 1: Operationalisation of Variables for Regression Analysis

\begin{tabular}{|l|l|l|}
\hline Variable Code & Description of Variable & Measurement \\
\hline Rent & Rental Value & Actual (A) \\
\hline TOFAC & Toilet Facilities & $\begin{array}{l}\text { 1=Open Defecation; }=\text { =Pit Toilet; } \\
\text { 3=Squatting Toilet; 4=Water Closet }\end{array}$ \\
\hline WATSUP & Water Supply System & $\begin{array}{l}\text { 1=No Water System; } 2=\text { Hand-Dug Well; } \\
\text { 3=Water Running within }\end{array}$ \\
\hline BATH & Bathroom & $\begin{array}{l}\text { 1=Open Bathroom; } 2=\text { Shared Bathroom; } 3 \\
\text { = En-suite Bathroom }\end{array}$ \\
\hline ELEC & Electricity Supply & $\begin{array}{l}\text { 1=1-3; 2=4-6; 3=7-9; 4=10-12; 5=Above } \\
\text { 12 (Hours per Day) }\end{array}$ \\
\hline SECSYST & Security System & $\begin{array}{l}\text { 1=No Security; 2=Community Security; } \\
\text { 3=Independent Security }\end{array}$ \\
\hline FENCE & Fencing & $\begin{array}{l}\text { 1=No Fence; 2=Fenced without Gate; } \\
\text { 3=Fenced with Gate }\end{array}$ \\
\hline ACC & Access Road to Property & $\begin{array}{l}\text { 1=Ungraded Road; }=\text { Graded Road; } \\
\text { 3=Tarred Road }\end{array}$ \\
\hline
\end{tabular}

\section{Data Analysis and Discussion of Results}

This section presents the results of the data gathered from the occupiers of the various hostel accommodation types around FUTA South Gate. The results are detailed in Tables $2-10$.

In order to have an understanding of the private student's housing around FUTA South Gate, Table 2 shows the type of students' housing that are predominant and their distances from the University's gate.

Table 2: Characteristics of Students' Hostels/Housing around FUTA South Gate

\begin{tabular}{|l|l|c|c|}
\hline Property Characteristics & \multicolumn{1}{|c|}{ Description } & Frequency & Percentage \\
\hline \multirow{5}{*}{ Students Housing Type } & Single room self-contained & 348 & 89.2 \\
& apartment & 28 & 7.2 \\
& 2-Bedroom flat & 14 & 3.6 \\
\hline \multirow{5}{*}{ 3istance of Property from } & Total & $\mathbf{3 9 0}$ & $\mathbf{1 0 0 . 0}$ \\
\cline { 2 - 4 } FUTA South Gate & $<201$ metres & 184 & 47.2 \\
& $201-400$ metres & 122 & 31.3 \\
& $401-600$ metres & 40 & 10.3 \\
& $601-800$ metres & 12 & 3.0 \\
& $>800$ metres & 32 & 8.2 \\
\cline { 2 - 4 } & Total & $\mathbf{3 9 0}$ & $\mathbf{1 0 0 . 0}$ \\
\hline
\end{tabular}

Table 2 reveals that the type of students' hostels occupied most frequently by respondents are the single room self-contained apartments with a response 
rate of $89.2 \%$, while $28(7.2 \%)$ and $14(3.6 \%)$ of respondents live in 2bedroom and 3-bedroom apartments respectively. This indicates that investors are more interested in developing single room self-contained apartments around FUTA South Gate because that is what is in high demand (Sawyerr \& Yusof, 2013; Adebisi et al., 2017). A single room self-contained apartment is designed for a sole occupant with a toilet, bathroom and kitchen enclosed. This affords student occupiers convenience and privacy without having to share these facilities with other tenants within the same building. Furthermore, Table 2 indicates that most residential property types are near the school gate. About $78.5 \%$ of the sampled respondents live in apartments not further than $400 \mathrm{~m}$ from the school's gate, while $21.5 \%$ live in properties that are more than $400 \mathrm{~m}$ away from the school gate. Thus, the students have quick access to the university's facilities without having to go a long distance

Some basic facilities required for good housing such as toilet facilities, water, bathroom, electricity, security fencing and access road were examined. These facilities are basic to human health and for the enjoyment of any housing or neighborhood (Wang et al., 2019). To this end, the characteristics pf the housing facilities were categorised using the above as a guiding framework. Table 3 below identifies the characteristics of the housing facilities in the study area.

Table 3: Characteristics of Students' Housing Facilities at FUTA South Gate

\begin{tabular}{|c|c|c|c|}
\hline Type of Facilities & Description & Frequency & Percentage \\
\hline \multirow{5}{*}{ Toilet Facilities } & No toilet facilities & 4 & 1.0 \\
\hline & Latrine & 10 & 2.6 \\
\hline & Squat Toilet & 66 & 16.9 \\
\hline & $\begin{array}{l}\text { Water Closet (Western } \\
\text { Toilet) }\end{array}$ & 310 & 79.5 \\
\hline & Total & 390 & 100.0 \\
\hline \multirow{4}{*}{$\begin{array}{l}\text { Water Supply } \\
\text { System }\end{array}$} & No Water in the Building & 28 & 7.2 \\
\hline & Hand-Dug Well & 98 & 25.1 \\
\hline & Running Water & 264 & 67.7 \\
\hline & Total & 390 & 100.0 \\
\hline \multirow{4}{*}{ Bathroom } & Open-air Bathroom & 10 & 2.5 \\
\hline & Shared Bathroom & 72 & 18.5 \\
\hline & Bathroom en-suite & 308 & 79.0 \\
\hline & Total & 390 & 100.0 \\
\hline \multirow{6}{*}{ Electricity Supply } & $1-3$ hours & 68 & 17.4 \\
\hline & 4-6 hours & 230 & 59.0 \\
\hline & 7-9 hours & 78 & 20.0 \\
\hline & $10-12$ hours & 4 & 1.0 \\
\hline & Above 12 hours & 10 & 2.6 \\
\hline & Total & 390 & 100.0 \\
\hline \multirow{3}{*}{ Fencing } & No fence & 92 & 23.6 \\
\hline & Fence without Gate & 66 & 16.9 \\
\hline & Fence with Gate & 232 & 59.5 \\
\hline
\end{tabular}




\begin{tabular}{|c|c|c|c|}
\hline & Total & 390 & 100.0 \\
\hline \multirow{4}{*}{ Security System } & No Security & 142 & 36.4 \\
\hline & Community Security & 124 & 31.8 \\
\hline & Independent Security & 124 & 31.8 \\
\hline & Total & 390 & 100.0 \\
\hline \multirow{4}{*}{$\begin{array}{l}\text { Access Road to } \\
\text { Property }\end{array}$} & Ungraded Road & 164 & 42.1 \\
\hline & Graded Road & 146 & 37.4 \\
\hline & Tarred Road & 80 & 20.5 \\
\hline & Total & 390 & 100.0 \\
\hline
\end{tabular}

Table 3 shows the characteristics of the facilities provided in off-campus student housing around FUTA South Gate. From Table 3, toilet facilities tend to be a water closet $(79.5 \%)$ with bathroom en-suite. This is evident with a $79.5 \%$ and $79.0 \%$ response rates respectively. However, there are still some residential students' hostels with old traditional toilet facilities like the latrines or even no toilet facility. While $16.9 \%$ of the respondents have a squatting type water closet in their residences, $2.6 \%$ use pit latrine. Further, $1.0 \%$ of the respondents have no toilet facility in their hostels, therefore, and have to improvise using a bush or by digging holes and using them as toilets. Furthermore, $2.5 \%$ of the respondents make use of open-air bathroom, which are located outside the building, while $18.5 \%$ of the respondents live in apartments where the bathrooms, though located within the building, are shared by all those living in the compound. From these results, one can conclude that most off-campus accommodations have the modern type facilities which can bring satisfaction to the occupiers otherwise the students may have intentions to relocate (Wang et al., 2019).

Over two thirds $(67.7 \%)$ of the respondents live in houses with running water in the building (toilets, bathrooms and kitchens). Water is highly essential for human survival, and any building that readily provides that conveniently without the occupiers having to go in search for it, attracts prospective tenants. However, $25.1 \%$ and $7.2 \%$ of the respondents respectively still live in apartments where they either fetch water from a well within the compound or go outside to other compounds in search of potable water. Table 3 further reveals the level of electricity supply (hours per day) and shows that most accommodation in the area enjoys no more than 6 hours of electricity per day (76.4\%). Olaniyan, et al. (2018) judge this as problematic since electricity is essential for living and productivity, especially in the student environment. The implication of this is that many students who can afford the use of generators will spend more of their money, while others who cannot will stay without electricity for the greater part of the day.

In terms of other housing facilities, Table 3 reveals that $59.5 \%$ of the residential properties are fenced with a gate for adequate protection. However, $23.6 \%$ and $16.9 \%$ of the respondents live in apartments without a fence or with a fence without gates. This may leave the inhabitants of these accommodations, especially the female ones, who are particularly vulnerable to attacks from criminals and even dangerous animals. Similarly, $36.4 \%$ of the properties do not have any operating security system for the safety of its occupants. While FUTA is a relatively peaceful area with minimal cases of 
theft and violence, good accommodation should provide all the essential facilities required for good living and safety, which will in turn bring added satisfaction to the occupants. After all, housing is expected to meet the sustainable development characteristics of basic human needs (MacLaren, 1996) such as safety and conducive living environment.

From the analysis, most of the facilities provided in off-campus accommodation are adequate. Furthermore, many have modern aspects due to recent developments and a surge in student's population as observed by Adebisi et al. (2015). However, some of the properties are still deficient in the provision of these essential facilities especially given the continued use of pit toilets, out-building bathrooms and some without running water. Some of these features persist given that old buildings are frequently repurposed as student housing/hostels to meet the demand. When demand is higher than supply, students make do with what they can get ahold of, even when the rent does not match utility offered by the accommodation. Sometimes, these students would have to live at an extra cost since they will have to provide some of these facilities that are not available in the properties by themselves. It could also lead to distractions from their studies and subsequently hamper the highly educated workforce needed for a growing economy like Nigeria. When satisfaction is tampered with, it can also bring about difficulties with tenants and subsequently rent defaults, which is not good for an investment.

A cross-tabulation was carried out to show the level of satisfaction or dissatisfaction of the students with the rents they pay for the different types of student housing around FUTA South Gate. This is presented in Table 4.

Table 4: Students' Level of Satisfaction with Rent Paid

\begin{tabular}{|l|c|c|c|c|c|c|}
\hline \multirow{2}{*}{ Residential Property Type } & \multicolumn{2}{|c|}{ Satisfied with Rent } & Not Satisfied with Rent & \multicolumn{2}{c|}{ Total } \\
\cline { 2 - 7 } & Frequency & Percentage & Frequency & Percentage & Frequency & Percentage \\
\hline Single room self-contained & 200 & $51.3 \%$ & 148 & $37.9 \%$ & 348 & $89.2 \%$ \\
\hline 2-Bedroom & 22 & $5.6 \%$ & 6 & $1.6 \%$ & 28 & $7.2 \%$ \\
\hline 3-Bedroom & 10 & $2.6 \%$ & 4 & $1.0 \%$ & 14 & $3.6 \%$ \\
\hline Total & $\mathbf{2 3 2}$ & $\mathbf{5 9 . 5 \%}$ & $\mathbf{1 5 8}$ & $\mathbf{4 0 . 5 \%}$ & $\mathbf{3 9 0}$ & $\mathbf{1 0 0 \%}$ \\
\hline
\end{tabular}

Table 4 shows the number of respondents who are satisfied and/or dissatisfied with the rent paid for the residential hostel occupied around FUTA South Gate. From the Table, 59.5\% of students are satisfied with the rent they pay, while $40.5 \%$ are dissatisfied. Out of the $59.5 \%$ who are satisfied, $51.3 \%$ live in single room self-contained apartments, $5.6 \%$ in 2-bedroom flats, while $2.6 \%$ live in 3-bedroom flats. Also, $37.9 \%$ of the dissatisfied students reside in a single room self-contained apartment, while $1.6 \%$ and $1.0 \%$ live in 2bedroom and 3-bedroom flats respectively. The results show that more students are satisfied with the rent they pay than those who are not satisfied.

In Tables 5 and 6, a T-test was employed to ascertain the level of difference in the rents paid by the students who are satisfied and dissatisfied, and how significant the difference is. 
Table 5: Group Statistics of Students' Housing Mean Rental Values

\begin{tabular}{|l|l|r|r|r|r|}
\hline Residential Property Type & \multicolumn{1}{|c|}{ Group } & N & $\begin{array}{c}\text { Mean Rent } \\
\text { (A) }\end{array}$ & $\begin{array}{c}\text { Std. } \\
\text { Deviation }\end{array}$ & $\begin{array}{c}\text { Std. Error } \\
\text { Mean }\end{array}$ \\
\hline \multirow{2}{*}{ Single room self-contained } & Satisfied & 200 & $81,140.00$ & $22,459.800$ & $1,588.148$ \\
& Non-Satisfied & 148 & $69,743.24$ & $23,117.453$ & $1,900.243$ \\
\hline \multirow{2}{*}{ 2-Bedroom } & Satisfied & 22 & $134,818.18$ & $28,691.522$ & 6117.053 \\
& Non-Satisfied & 6 & $128,333.33$ & $42,972.860$ & 17543.596 \\
\hline \multirow{2}{*}{ 3-Bedroom } & Satisfied & 10 & $153,400.00$ & $615,34.453$ & 19458.903 \\
& Non-Satisfied & 4 & $206,000.00$ & .000 & .000 \\
\hline
\end{tabular}

Table 5 shows the group statistics of the number of residential properties occupied by students who are satisfied and unsatisfied with the rent paid for their apartments, as well as the mean rental values, the standard deviation and error mean. The result suggests that higher prices on similar spaces cause dissatisfaction. This can be seen in the relationship between the satisfied and unsatisfied students in a 3 Bedroom space as those who are not satisfied pay a higher mean rent than those who are satisfied. This dissatisfaction with rent paid is expected as the student occupiers would have used the excess rent for other personal provisions. However, for a single room self-contained apartment and 2 Bedroom apartments, the students that are satisfied with their rent pay even higher mean rent than that paid by the non-satisfied students. For these students to be satisfied with paying higher mean rental value, it implies that they must have been enjoying certain incentives in the property. Thus, their satisfaction with higher rental value must have been influenced by some factors which may be internal or external to the property being occupied by the students. The significant level of mean rental value difference is presented in Table 6.

Table 6: T-Test for Equality of Mean Rental Values of Satisfied and Unsatisfied Students

\begin{tabular}{|c|c|c|c|c|c|c|c|c|c|c|}
\hline \multirow{3}{*}{\multicolumn{2}{|c|}{$\begin{array}{l} \\
\text { Residential } \\
\text { Property } \\
\text { Type }\end{array}$}} & \multicolumn{2}{|c|}{$\begin{array}{c}\text { Levene's Test } \\
\text { for Equality of } \\
\text { Variances }\end{array}$} & \multicolumn{7}{|c|}{ t-test for Equality of Means } \\
\hline & & \multirow[t]{2}{*}{$\mathbf{F}$} & \multirow[t]{2}{*}{ Sig. } & \multirow[t]{2}{*}{$\mathbf{T}$} & \multirow{2}{*}{ Df } & \multirow{2}{*}{$\begin{array}{l}\text { Sig. (2- } \\
\text { tailed) }\end{array}$} & \multirow{2}{*}{$\begin{array}{c}\text { Mean } \\
\text { Difference }\end{array}$} & \multirow{2}{*}{$\begin{array}{l}\text { Std. Error } \\
\text { Difference }\end{array}$} & \multicolumn{2}{|c|}{$\begin{array}{l}\text { 95\% Confidence Interval } \\
\text { of the Difference }\end{array}$} \\
\hline & & & & & & & & & Lower & Upper \\
\hline \multirow{2}{*}{ 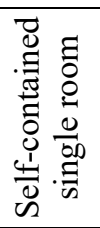 } & $\begin{array}{l}\text { Equal variances } \\
\text { assumed }\end{array}$ & 1.558 & .213 & 4.622 & 346 & .000 & 11396.757 & 2465.832 & 6546.850 & 16246.663 \\
\hline & $\begin{array}{l}\text { Equal variances } \\
\text { not assumed }\end{array}$ & & & 4.602 & 311.729 & .000 & 11396.757 & 2476.517 & 6523.954 & 16269.559 \\
\hline \multirow{2}{*}{$\begin{array}{l}\Xi \\
0 \\
0 \\
0 \\
0 \\
\infty \\
\text { ح }\end{array}$} & $\begin{array}{l}\text { Equal variances } \\
\text { assumed }\end{array}$ & 2.024 & .167 & .441 & 26 & .663 & 6484.848 & 14709.472 & -23750.905 & 36720.602 \\
\hline & $\begin{array}{l}\text { Equal variances } \\
\text { not assumed }\end{array}$ & & & .349 & 6.268 & .738 & 6484.848 & 18579.454 & -38511.035 & 51480.732 \\
\hline \multirow{2}{*}{ 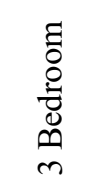 } & $\begin{array}{l}\text { Equal variances } \\
\text { assumed }\end{array}$ & 15.163 & .002 & -1.668 & 12 & .121 & -52600.000 & 31527.025 & -121291.488 & 16091.488 \\
\hline & $\begin{array}{l}\text { Equal variances } \\
\text { not assumed }\end{array}$ & & & -2.703 & 9.000 & .024 & -52600.000 & 19458.903 & -96619.096 & -8580.904 \\
\hline
\end{tabular}


In Table 6, the Levene's test for the equality of variance is not significant for the single room self-contained apartments $(\mathrm{p}=0.213)$, as well as the 2Bedroom flat $(p=0.167)$. The Levene's test is used to test whether the variance of the mean rent for the two groups (satisfied and unsatisfied) is the same (Pallant, 2011). The result demonstrated a significance in the equality of variance for a 3 -Bedroom flat $(\mathrm{p}=0.002)$. The equal variance assumed in Table 6 is used for a single room self-contained and a 2-bedroom flat, while the equal variance is not assumed for a 3-bedroom flat. From the Table, there is a statistically significant difference in the mean rental values paid by the satisfied and unsatisfied students for a single room self-contained apartment $(\mathrm{p}=0.000)$ and a 3-Bedroom flat $(\mathrm{p}=0.024)$.

For single room self-contained apartments, satisfied students pay significantly higher rents than those who are unsatisfied by their rental price. Contrastingly, for 3-bedroom flats, dissatisfied students pay higher rent than those who are satisfied with the price. Perhaps this is due to the greater provisions of facilities offered in the single room self-contained apartments compared to the 3 Bedroom flats. However, for 2-Bedroom flats, there is no statistically significant difference in the mean rental value of housing occupied by either satisfied or dissatisfied rent-paying students $(p=0.663)$. This result shows that a difference in rental values exist in single room selfcontained apartments around FUTA, due to its provision of and privatisation of facilities in the neighbourhood. This finding aligns with that of Mbee and Akpoghomeh (2017), who observed significant variation in the rental patterns of student housing around institutions.

In Table 7, the students' responses were sought on their level of satisfaction with the various facilities provided in their accommodation. This was conducted on a 5-point Likert scale, with ' 5 ' being the highest level of satisfaction, and ' 1 ', the highest level of dissatisfaction. A mean score (MS) of 3.41-5.0 shows satisfaction, 2.61-3.40 indicates undecided while anything below 2.61 indicates dissatisfaction with facilities.

Table 7: Students' Level of Satisfaction with Facilities

\begin{tabular}{|l|c|c|c|c|c|c|c|}
\hline \multirow{2}{*}{ Facilities } & \multicolumn{5}{|c|}{ Satisfaction Rating } & \multirow{2}{*}{ Mean } & \multirow{2}{*}{ Rank } \\
\cline { 2 - 7 } & $\mathbf{5}$ & $\mathbf{4}$ & $\mathbf{3}$ & $\mathbf{2}$ & $\mathbf{1}$ & & 1 \\
\hline Toilet Facilities & $124(31.79 \%)$ & $152(38.97 \%)$ & $88(22.56 \%)$ & $14(3.59 \%)$ & $12(3.08 \%)$ & 3.93 & 1 \\
Bathroom & $92(23.59 \%)$ & $186(47.69 \%)$ & $90(23.08 \%)$ & $20(5.13 \%)$ & $2(0.51 \%)$ & 3.89 & 2 \\
Fencing & $92(23.59 \%)$ & $148(37.95 \%)$ & $68(17.44 \%)$ & $50(12.82 \%)$ & $32(8.21 \%)$ & 3.56 & 3 \\
Water Supply System & $70(17.95 \%)$ & $160(41.03 \%)$ & $68(17.44 \%)$ & $64(16.41 \%)$ & $28(7.18 \%)$ & 3.46 & 4 \\
Electricity Supply & $38(9.74 \%)$ & $142(36.41 \%)$ & $134(34.36 \%)$ & $58(14.87 \%)$ & $18(4.62 \%)$ & 3.32 & 5 \\
Security System & $24(6.15 \%)$ & $156(40.00 \%)$ & $118(30.26 \%)$ & $58(14.87 \%)$ & $34(8.72 \%)$ & 3.20 & 6 \\
Access Road to Property & $44(11.28 \%)$ & $130(33.33 \%)$ & $86(22.05 \%)$ & $84(21.54 \%)$ & $46(11.79 \%)$ & 3.11 & 7 \\
\hline
\end{tabular}

Table 7 illustrates the level of satisfaction students feel toward the facilities in their off-campus accommodation: toilet facilities (MS=3.93), bathroom $(\mathrm{MS}=3.89)$, fencing ( $\mathrm{MS}=3.56)$ and water supply system $(\mathrm{MS}=3.46)$. Thus, students are largely satisfied with these features. It is important to note that these facilities are subjective and specific to each student's hostel, however 
they must be adequately installed and functioning to warrant the students' satisfaction. The responses also suggest that students are undecided about the neighbourhood facilities such as electricity supply, security system and access roads to the property with mean scores of $3.32,3.20$ and 3.11 respectively. This implies that some of the facilities in these hostels are adequate, and this must have incentivised the occupiers to be satisfied with the rent that they are paying especially in a single room self-contained apartment. However, the access road to the property, the level of security and the electricity supply system is only encouraging to some extent as most student occupiers are not satisfied with their provisions. This study supports the notion that not all required facilities, needed for convenience and value enhancement, are adequately provided for by homeowners as revealed by Sawyerr and Yusof (2013).

Table 8 shows the cross-tabulation of students' rent satisfaction with the satisfaction derived from the facilities provided. The results revealed that students who are satisfied with the facilities provided such as toilet (4.18), water supply (3.76), type of bathroom (4.07), electricity supply (3.44) and fencing (3.78) in their apartments are satisfied with the rents they pay, while they are undecided on the impact of security systems and access roads on their rental choices. The students who showed dissatisfaction with rents they pay are undecided and/or are not satisfied with the facilities being provided in their accommodation except for the toilet facilities (3.56) and type of bathroom provided (3.62). Thus, when students are satisfied with the facilities available to them, they are willing to pay more than market rent for their apartments. However, when the rent is excessively higher than what is obtainable in the market, as is the case in 3 Bedroom flats, dissatisfaction will set in even when the facilities are adequate.

Table 8: Cross Tabulation of Students' Rent Satisfaction with Facilities Satisfaction

\begin{tabular}{|c|c|c|c|c|c|c|c|c|c|}
\hline \multirow{2}{*}{ Facilities } & \multirow{2}{*}{$\begin{array}{l}\text { Rent } \\
\text { Satisfaction }\end{array}$} & \multicolumn{5}{|c|}{ Level of Satisfaction with Facilities } & \multicolumn{3}{|c|}{ Chi-square } \\
\hline & & 1 & 2 & 3 & 4 & 5 & Mean & Value & Sig \\
\hline \multirow{3}{*}{$\begin{array}{l}\text { Toilet } \\
\text { Facilities }\end{array}$} & Satisfied & 4 & 4 & 32 & 98 & 94 & \multirow{3}{*}{$\begin{array}{l}4.18 \\
3.56\end{array}$} & \multirow[t]{3}{*}{21.877} & \multirow[t]{3}{*}{0.000} \\
\hline & Not Satisfied & 8 & 10 & 56 & 54 & 30 & & & \\
\hline & Total & 12 & 14 & 88 & 152 & 124 & & & \\
\hline \multirow{3}{*}{$\begin{array}{l}\text { Water } \\
\text { Supply } \\
\text { System }\end{array}$} & Satisfied & 10 & 18 & 38 & 118 & 48 & \multirow{3}{*}{$\begin{array}{l}3.76 \\
3.03\end{array}$} & \multirow[t]{3}{*}{24.478} & \multirow[t]{3}{*}{0.000} \\
\hline & Not Satisfied & 18 & 46 & 30 & 42 & 22 & & & \\
\hline & Total & 28 & 64 & 84 & 160 & 70 & & & \\
\hline \multirow{3}{*}{$\begin{array}{l}\text { Type of } \\
\text { Bathroom }\end{array}$} & Satisfied & 0 & 8 & 30 & 132 & 62 & \multirow{3}{*}{$\begin{array}{l}4.07 \\
3.62\end{array}$} & \multirow[t]{3}{*}{22.095} & \multirow[t]{3}{*}{0.000} \\
\hline & Not Satisfied & 2 & 12 & 60 & 54 & 30 & & & \\
\hline & Total & 2 & 20 & 90 & 186 & 92 & & & \\
\hline \multirow{3}{*}{$\begin{array}{l}\text { Electricity } \\
\text { Supply } \\
\text { System }\end{array}$} & Satisfied & 10 & 32 & 60 & 106 & 24 & \multirow{3}{*}{$\begin{array}{l}3.44 \\
3.14\end{array}$} & \multirow[t]{3}{*}{13.176} & \multirow[t]{3}{*}{0.010} \\
\hline & Not Satisfied & 8 & 26 & 74 & 36 & 14 & & & \\
\hline & Total & 18 & 58 & 134 & 142 & 38 & & & \\
\hline \multirow{3}{*}{$\begin{array}{l}\text { Security } \\
\text { System }\end{array}$} & Satisfied & 14 & 30 & 64 & 110 & 14 & \multirow{3}{*}{$\begin{array}{l}3.34 \\
2.99\end{array}$} & \multirow[t]{3}{*}{7.706} & \multirow[t]{3}{*}{0.103} \\
\hline & Not Satisfied & 20 & 28 & 54 & 46 & 10 & & & \\
\hline & Total & 34 & 58 & 118 & 156 & 24 & & & \\
\hline
\end{tabular}




\begin{tabular}{|l|l|l|l|l|l|l|l|l|l|}
\hline \multirow{3}{*}{ Fencing } & Satisfied & 12 & 24 & 26 & 112 & 58 & 3.78 & 19.238 & 0.001 \\
& Not Satisfied & 20 & 26 & 42 & 36 & 34 & 3.24 & & \\
\cline { 2 - 8 } & Total & $\mathbf{3 2}$ & $\mathbf{5 0}$ & $\mathbf{6 8}$ & $\mathbf{1 4 8}$ & $\mathbf{9 2}$ & & & \\
\hline \multirow{2}{*}{$\begin{array}{l}\text { Access } \\
\text { Road to } \\
\text { Property }\end{array}$} & Satisfied & 22 & 32 & 52 & 100 & 26 & 3.33 & 17.491 & 0.002 \\
\cline { 2 - 8 } & Not Satisfied & 24 & 52 & 34 & 30 & 18 & 2.78 & & \\
\hline
\end{tabular}

The Spearman Rank Correlation analysis in Table 9 emphasises the statistically and significantly positive relationship between the satisfaction with rent paid and the facilities provided. The correlation is only strong for toilet facilities (0.321). Furthermore, the results show that the more students are satisfied with the housing facilities being provided, the more they become satisfied with the rent they pay. In other words, they are paying not only for the accommodation, but for the enjoyment of the facilities in the accommodation. When rents are high and there is no satisfaction with facilities provided, the students become dissatisfied with the rent and vice versa. Thus, this proves that there is a positive correlation between satisfaction with facilities provided in students' housing and satisfaction with rent paid.

\section{Table 9: Spearman Rank Correlations of Students' Rent Satisfaction and Facilities Provided}

\begin{tabular}{|l|c|c|c|}
\hline \multirow{2}{*}{ Facilities } & \multicolumn{2}{|c|}{ Satisfaction with Rent Paid } & \multirow{2}{*}{$\begin{array}{c}\text { Total } \\
\text { N }\end{array}$} \\
\cline { 2 - 3 } & $\begin{array}{c}\text { Correlation } \\
\text { Coefficient }\end{array}$ & Sig. (2-tailed) & \\
\hline Toilet Facilities & .321 & $.000^{*}$ & 390 \\
Water Supply & .297 & $.000^{*}$ & 390 \\
Bathroom & .262 & $.000^{*}$ & 390 \\
Electricity Supply & .177 & $.000^{*}$ & 390 \\
Security System & .172 & $.001^{*}$ & 390 \\
Fencing & .211 & $.000^{*}$ & 390 \\
Access Road & .227 & $.000^{*}$ & 390 \\
\hline
\end{tabular}

Table 10 presents the Multiple Regression result of the effect of facilities within residential accommodations on the rental values of the properties. The coefficient of Determination $\left(\mathrm{R}^{2}\right)$ shows that $34.3 \%$ of the variation in rental values for a single room self-contained apartment around FUTA South Gate is attributed to the independent variables being considered, and the model is significant at 0.000 level of significance. This implies that the result of the model can be relied on in predicting what happens in the residential rental market in FUTA. Furthermore, the results also reveals that type of water supply system $(p=0.000)$, bathroom $(p=0.000)$, access road to property $(p=$ $0.000)$ and type of security system $(p=0.005)$ significantly and positively affect rental values of a single room self-contained apartments around FUTA at a 99\% confidence level. Contrastingly, the type of toilet facilities significantly affect rent passing on the property type at 95\% level (0.077). The implication of this result is that improvement in the water supply system, bathroom system, access road, security system and toilet facility will significantly increase the rental values of the properties concerned. This 
finding is in tandem with the work of Adebayo (2006) who suggests that infrastructural facilities enhance the value of residential accommodation. Thus, developers should be mindful of these housing facilities to enable their developments to command high and satisfying rental values.

Table 10: Effect of Facilities Provision on Residential Property Rental Values

\begin{tabular}{|c|c|c|c|c|c|}
\hline \multirow{2}{*}{ Model } & \multicolumn{2}{|c|}{ Unstandardised Coefficients } & \multirow{2}{*}{$\begin{array}{c}\begin{array}{c}\text { Standardised } \\
\text { Coefficients }\end{array} \\
\text { Beta }\end{array}$} & \multirow{2}{*}{$\mathbf{t}$} & \multirow{2}{*}{ Sig. } \\
\hline & B & Std. Error & & & \\
\hline (Constant) & -18698.273 & 8649.778 & & -2.162 & .031 \\
\hline Toilet Facilities & 3334.541 & 1878.329 & .082 & 1.775 & $.077^{*}$ \\
\hline Water Supply System & 6820.764 & 1898.427 & .183 & 3.593 & $.000^{* * *}$ \\
\hline Bathroom & 16800.308 & 2309.133 & .348 & 7.276 & $.000^{* * *}$ \\
\hline Electricity Supply & -263.389 & 1282.521 & -.009 & -.205 & .837 \\
\hline Security System & 3739.390 & 1335.265 & .130 & 2.800 & $.005^{* *}$ \\
\hline Fencing & 918.823 & 1380.742 & .033 & .665 & .506 \\
\hline Access Road to Property & 5467.541 & 1446.477 & .177 & 3.780 & $.000^{* * *}$ \\
\hline $\mathbf{R}^{2}$ & 0.343 & & & & \\
\hline F-Statistics & 25.370 & & & & \\
\hline Sig & 0.000 & & & & \\
\hline
\end{tabular}

\section{Conclusion}

This study has examined the level of students' satisfaction with private hostel facilities in FUTA South Gate. Further, we studied the relationship between students' satisfaction with private hostel facilities and rent satisfaction, and finally the effect of the hostel facilities on the rental values of the private hostels. The study employed both descriptive and inferential statistical analyses. It was found that not all the students are satisfied with the rent they pay because they are not satisfied with some of the facilities provided in the private hostels. The correlation analysis revealed a significant positive relationship between students' satisfaction with facilities and rent satisfaction. The satisfied student occupiers were seen to pay more for hostel accommodation (especially single room self-contained apartments) than those who were not satisfied. This study further revealed that students' rent satisfaction is driven by their satisfaction with adequate facilities and this has implications for the rental values of students' hostels. Thus, the rental value of private student's housing is not merely a function of student's satisfaction with the rent they are paying, but also a function of their satisfaction with the facilities provided in the building as well as the accessibility to the building. When these facilities are lacking or inadequate, it should be reflected in lower rent passing.

Since rental value is also dependent on the satisfaction of students with the adequate provision of facilities in off-campus hostels, developers and investors in student housing should provide more adequate housing facilities 
or improve the facilities already in their properties. This will increase the satisfaction level of the occupiers with the facilities.

\section{References}

Adebayo, M.A. (2006). The State of Urban Infrastructure and its Effects on Property Values in Lagos. Journal of Land Use and Development Studies, 2(1), pp.108-122.

Adebisi, O.S., Ezeokoli, N.B., Oletubo, A.A. \& Alade, T.J. (2015). Rental Analysis of Residential Properties the Federal University of Technology, Akure, Nigeria. Journal of Economics and Sustainable Development, 6(10), pp.140-147.

Adebisi, O.S., Oletubo, A.A., Alade, T.J. \& Ekpekpe, A. (2017). Perspectives of Students on Private Hostel Facilities in Proximity to the Federal University of Technology, Akure, Nigeria. Journal of Poverty, Investment and Development, 33, pp.31-36.

Adenikinju, A.F. (2005). Analysis of the cost of infrastructure failures in a developing economy: the case of the electricity sector in Nigeria. African Economic Research Consortium (AERC) Research Paper 148. Nairobi.

Ajanlekoko, J. S. (2001), Sustainable Housing Development in Nigeria- The Financial and Infrastructural Implication. In Proceedings of the International Conference on Spatial Information for Sustainable Development. Nairobi, Kenya. 2-5 October.

Aluko, O.E. (2011) the Assessment of Housing Situation among Students in the University of Lagos. African Research Review, 5(3), pp.104-118.

Asare-Kyire, L., Appienti, W.A., Forkuoh, S. K. \& Osei, A. (2012). The Economics of Private Hostels in Ghana: A Case of Private Hostels on KNUST Campus. International Journal of Social Science Tomorrow, 1(8), pp.1-18.

Attakora-Amaniampong, E., Ameyaw, S. \& Akortsu, W. (2017). Qualitative Adequacy of Students Hostels in Wa, Ghana. Civil Engineering and Architecture 5(6), pp.193-206.

Azeez, T., Taiwo, D., Mogaji-Allison, B. \& Bello, A. (2016). Comparative Assessment of Students' Satisfaction with Hostel Accommodation in Selected Private Universities in Ogun State, Nigeria. European Scientific Journal, 12(32), pp.410-425.

Bello, M.O. \& Bello, V.A. (2006). Sustainable Investment in Nigerian Housing Sector: What Went Wrong? In The Built Environment: Innovation Policy and Sustainable Development. A.I. Okewole et al. (eds.). Department of Architecture, Covenant University. pp.356-364.

Danso, A.K. \& Hammond, S.F. (2017). Level of Satisfaction with Private Hostels around Knust Campus. International Journal of Science and Technology 6(3), pp. 719-727.

Egunjobi L. (1999). Our Gasping Cities. An Inaugural Lecture delivered at the University of Ibadan, $21^{\text {st }}$ October, 1999.

Ezimuo, P.N., Onyejiaka, C.J. \& Emoh, F.I. (2014). Sources of real estate finance and their impact on property development in Nigeria: A case 
of Mortgage institutions in Lagos Metropolis. British Journal of Environmental research, 2(2), pp.35-58.

Henderson, J.V. \& Ioannides, Y.M. (1987). Owner Occupancy: Investment vs Consumption Demand. Journal of Urban Economics, 21(2), pp.228-241.

Hodge, T. (1997). Towards a conceptual framework for assessing progress toward sustainability. Social Indicators Research, 40(1-2), pp.5-98.

Horn, L., Peter, K. \& Rooney, K. (2002). Profile of Undergraduates in U.S. Postsecondary institutions: 1999-2000. Statistical Analysis Report. National Postsecondary Student Aid Study. Washington, DC: U.S. Department of Education. National Center for Education Statistics.

Idakwo, J.A., Igbokwe, D.O. \& Ndom, R.J.E. (2012). Overcrowding, Age and Gender Differences in the Manifestation of State Anxiety among Undergraduate Students in a Nigerian Public University. IFE Psychologia: An International Journal, 20(1), 323 - 337.

Joachim, A.O. \& Olachi, N.U. (2010). An Assessment of the Management of Students' Hostels of Tertiary Institutions in Owerri, Imo state. Tropical Built Environment Journal (TBEJ) 1(1), pp.11-20.

Khozaei, F., Hassan, A.S. \& Khozaei, Z. (2010). Undergraduate Students' Satisfaction with Hostel and Sense of Attachment to Place: Case Study of University Sains Malaysia. American Journal of Engineering and Applied Sciences 3(5), pp.516-520.

Khozaei, F., Ayub, N. Hassan A.S. \& Khozaei, Z. (2010). The factors predicting Student's satisfaction with University Hostels, case study, Universiti sains Malaysia. Journal of Asian Culture and History, 2(2), pp. $148-158$.

Khozaei, F., Hassan A.S. \& Razak, N.A. (2011). Development and Validation of the student accommodation preferences instrument (SAPI). Journal of Building Appraisal, 6(3-4), pp.299-313.

Kothari, C. (2004). Research Methodology, Methods and Techniques. New Delhi: New Age International Publishers Limited.

MacLaren, V. (1996). Urban sustainability reporting. Journal of the American Planning Association, 62(2), pp.184-202.

Mbee, D.M. \& Akpoghomeh, O. (2017). Trends in Rent in Off-Campus Accommodation in Federal Universities in Southern Nigeria. Journal of Humanities and Social Sciences, 22(4), pp.1-6.

Mohammad, M.I., Gambo, Y.L. \& Omirin, M.M. (2012). Assessing Facilities Management Service in Postgraduate Hostel Using Servqual Technique. Journal of Emerging Trends in Economics and Management Sciences, 3(5), pp.485-490.

Mudau, T.J. (2017). An Exploration of the challenges faced by students residing off-campus in rural Universities in South Africa. Journal of Gender and Behaviour, 15(4), pp.10568-10580.

Nimako, S.G. \& Bondinuba, F.K. (2013). Relative Importance of Student Accommodation Quality in Higher Education. Current Research Journal of Social Sciences, 5(4), pp.134-142.

Nkegbe, P.K., Kuunibe N. \& Abdul-Mumin, Y. (2012). Choice of transport mode by non-resident university students in Ghana. International Journal of Business and Social Science, 3(20), pp.136-142. 
The National University Commission (NUC). (2000). Approved Policy for Private Sector Participation in the Provision and Management of Students Hostel in Nigeria Tertiary Institution. Memo to all Vice Chancellors, pp.1-8.

Ogeah, F.N. \& Ajalaye, V. (2011). Students' off-campus residence and impact on localities: The Case of University of Benin and Ekosodin village. Global Journal of Social Sciences, 10(1\&2), pp.37-43.

Olaniyan, K., McLellan, B.C., Ogata, S. \& Tezuka, T. (2018). Estimating Residential Electricity Consumption in Nigeria to Support Energy Transitions. Journal of Sustainability, 10(1440), pp.10-22.

Olatubara, C.O. (2008). The Dynamics of Households Residential Choice in Nigeria. The Fifteenth Faculty Lecture delivered at the Faculty of Social Sciences, University of Ibadan.

Olujimi, J.A.B. (2010), Analysis of the Relationships of Infrastructural Facilities in the Determination of Rental Values of Residential Properties in Akure, Nigeria. Art and Social Science Journal, 10(1), pp.1-11.

Oyetunji, A.K. (2014). The effects of students' housing on academic performance in Federal University of Technology, Akure. Masters Dissertation. Department of Estate Management, Federal University of Technology, Akure, Nigeria.

Pallant, J. (2011). SPSS Survival Manual: a step by step guide to data analysis using SPSS. (4th edition). China: Everbest Printing Co.

Rugg, J., Rhodes, D. \& Jones, A. (2000). The nature and impact of student demand on housing markets, York: JRF.

Sawyerr, P.T. \& Yusof, N. (2013), Student satisfaction with hostel facilities in Nigerian polytechnics, Journal of Facilities Management, 11(4), pp.306-322

Sharma, Y. (2012). Fast Pace of Higher Education Enrolment Growth Predicted Too Slow. University World News. [Online]. Available at: https://www.universityworldnews.com/post.php?story=2012031308 172724\&query=Iran (Accessed: 12 October, 2020).

Thomsen, J. \& Eikemo, T.A. (2010). Aspects of student housing satisfaction: a quantitative study. Journal of housing and the Built Environment, 25(3) pp.273-293.

Thorncroft, M. (1978). Principle of Estate Management. ( $1^{\text {st }}$ Edition). London: Estate Gazette.

Wang, D., He, S., Webster, C. \& Zhang, X. (2019). Unravelling Residential Satisfaction and Relocation Intentions in Three Urban Neighborhood Types in Guangzhou, China. Habitat International, 85, pp.53-62.

Yusuff, O.S. (2011). Students Access to Housing: A case of Lagos State University Nigeria, Journal of Sustainable Development, 4(2), pp.107-122. 